Military Technical College

Kobry El-Kobbah, Cairo, Egypt

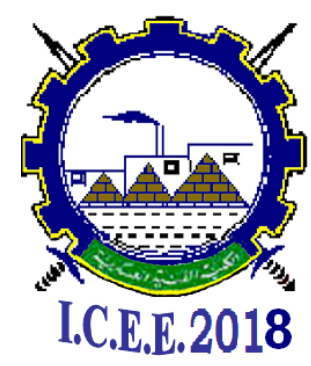

$9^{\text {th }}$ International Conference on

Chemical \& Environmental

Engineering

3-5 April 2018

NRT-3

\title{
Development of Nuclear Reactors Technology and General Feature of Egypt Nuclear Power Plants
}

\author{
Prof. Dr. / Sayed A. El-Mongy
}

\begin{abstract}
Nuclear reactors technology has been dramatically developed since the era of the first Fermi Pile fission reactor during the $2^{\text {nd }}$ world war.

Generation I and II reactors had been used for peaceful electricity generation and military (e.g. nuclear submarines) purposes.

As a matter of fact, Generation III and III+ were proposed, developed, deployed and currently in operation worldwide. Recently, floating units and SMR are available options. The Ge III++ is currently proposed.

The generation IV options; such as MSR, are intensively discussed through GIF. None of them has been commercially constructed.

Fusion experimental reactor is on the track and road of reactors technology development. It needs some time for full plasma confinement to be safely controllable.

Egypt has declared in 19 November 2015 and signed IGA for construction of 4 VVER Russian design reactors (pressurized water reactor) of $1200 \mathrm{MWe}$ each (4.8 GWe total) at ElDabaa site. In 11 December 2017, notices to proceed the contracts was signed in the presence of the president Abdel Fattah El Sisi. The Rosatom company will supplying Egypt with the nuclear fuel throughout the plant's entire operational lifetime. The first unit is scheduled to be commercially commissioned by 2026 . These reactors belong to Ge III+ that has post Fukushima features; advanced passive and active safety systems.

According to the ministry of planning; by 2030, these reactors will contribute in the electricity portfolio of Egypt by about $10.5 \%$. While, coal and renewable (solar and wind) sources will contribute by $15 \%$ and $21 \%$ percentage in 2020 respectively.

Egypt, based on these plans, is going to has strategic energy mix consists of fossil; steam, combined, hydro and renewable energy sources.
\end{abstract}

Ex- Vice Chairman of Egypt Nuclear Regulatory Authority (ENRRA)

sayedelmongy@ hotmail.com; Mobil: 01224312870 